\title{
Bevasizumab'a İyi Cevap Veren, Radyoterapi ve Temozolomid Tedavisine Yanıtsız Bir Erişkin Spinal Kord Astrositomu: Olgu Sunumu ve Literatür Derlemesi
}

Radiotherapy and Temozolomide Non-Responsive Adult Spinal Cord Astrocytoma with a Good Response to Bevacizumab: A Case Report and Literature Review

Aysegul UCUNCU KEFELI ${ }^{1}$, Suleyman HALIL ${ }^{2}$

\footnotetext{
${ }^{1}$ Kocaeli University School of Medicine, Department of Radiation Oncology, Kocaeli, Turkey

${ }^{2}$ Kocaeli State Hospital, Division of Medical Oncology, Kocaeli, Turkey
}

Özet

Spinal kord astrositomlarının (SKA) görülme sıklığı çok düşüktür ve bu insidans azlığı nedeniyle bu tümörlerin yönetimi zordur. Bu vakada, rekürren SKA’lı bir hastada, radyoterapi (RT) ve temozolomid (TMZ) dahil olmak üzere önceki tedavilerden fayda görmeyen bir hastada bevasizumab ile görülen iyi yanıtı bildirmekteyiz. Bevasizumab, yüksek dereceli gliomlarda yaygın olarak kullanılan ve SKA'lar için umut vaat eden bir anjiyogjenez inhibitörüdür, ancak SKA'larda bevasizumab kullanımı hakkında sınırlı veri bulunmaktadır. Bu yazıda, düşük dereceli SKA'lı bir vakada bevasizumab ile tama yakın cevap bildirerek literatüre önemli bir katkı eklemekteyiz.

Anahtar kelimeler: Bevasizumab, Temozolomid, Spinal kord astrositomu, Radyoterapi

\section{Abstract}

The incidence of spinal cord astrocytomas (SCAs) is very low and therefore, management of these tumors are challenging due to this paucity. In this report, a patient with a recurrent SCA was successfully treated with bevacizumab after failing to previous therapies including radiotherapy (RT) and temozolomide (TMZ). Bevacizumab is an angiogenesis inhibitor that is widely used in high grade gliomas and shows promise for SCAs but there is limited data about the usage of bevacizumab in SCAs. We herein add an important contribution to the literature by reporting a nearly total response to bevacizumab in a patient with low grade SCA.

Keywords: Bevacizumab, Temozolomide, Spinal cord astrocytoma, Radiotherapy

Yazışma Adresi: Aysegül Üçüncü KEFELİ, Kocaeli Üniversitesi Tıp Fakültesi Radyasyon Onkolojisi ABD, Kocaeli, Türkiye, Telefon: 0905053012982, Mail: dr_aysegull@hotmail.com

ORCID No (Sirasıyla): 0000-0002-0167-8636,0000-0001-9038-4455

Geliş tarihi: 09.07.2020

Kabul tarihi: 05.08.2020

DOI: $10.17517 /$ ksutfd.767351 


\section{INTRODUCTION}

Intramedullary spinal cord tumors (IMSCTs) are rarely seen tumors which account for $2-4 \%$ of central nervous system tumors. Spinal cord astrocytomas (SCAs) compromise only 30 to $40 \%$ of them with the remaining most common ones are ependymomas, and then rarely hemangioblastomas, gangliogliomas, germinomas, primary central nervous system (CNS) lymphomas, melanomas and metastasis from a primary malignancy (1). SCAs are difficult to manage due to low incidence rates and limited number of studies in the literature. Most SCAs are low grade (WHO grade II) but they are mostly infiltrative in nature (2). Maximal safe surgical resection is the only curative treatment option but total resection was reported as a difficult procedure (3). Observation is appropriate in totally resected tumors, while in subtotaly resected and recurrent tumors, the role of adjuvant radiotherapy $(\mathrm{RT})$ and chemotherapy $(\mathrm{CT})$ is not clear $(1,4,5)$.

Here, we describe a patient with an inoperable recurrent SCA, who showed progression after radiotherapy and temozolomide (TMZ) treatment but surprisingly showed a good treatment response to bevacizumab. While addressing this case, we reviewed the literature for the evidence based role of chemotherapy in the treatment of SCAs.

\section{CASE PRESENTATION}

A 44-year-old woman presented with back and leg pain in July 2012, started 15 months ago and progressed for 6 months. Thoracolomber magnetic resonance imaging (MRI) showed an intradural intramedullary 19x16.8x10 mm mass located at T12-L1 level obstructing the spinal canal and compressing the spinal cord, which was hyperintense in T1 weighted images, hypointense in T2 weighted images, without contrast enhancement in postcontrast series. In her neurologic examination, she had normal muscle strength on the upper extremities but she had left sided leg weakness $1+/ 5$ on the left lower limb. Her reflexes were intact and she had no bowel and bladder incontinence. Total laminectomy was performed at T11-L1 level and the mass was resected totally with neuronavigation method. Pathology examination showed diffuse astrocytoma WHO grade 2. Postoperative MRI showed no residual mass and adjuvant radiotherapy and chemotherapy were not given. After 5 years of follow up in November 2017, patient presented with bilateral lower extremity weakness and at this time, MRI of whole spine showed dural noduler enhancement and contrast enhanced lesions in T12-L1-L2, $\mathrm{T} 5$ and also at T9 vertebra level (Figure 1A).
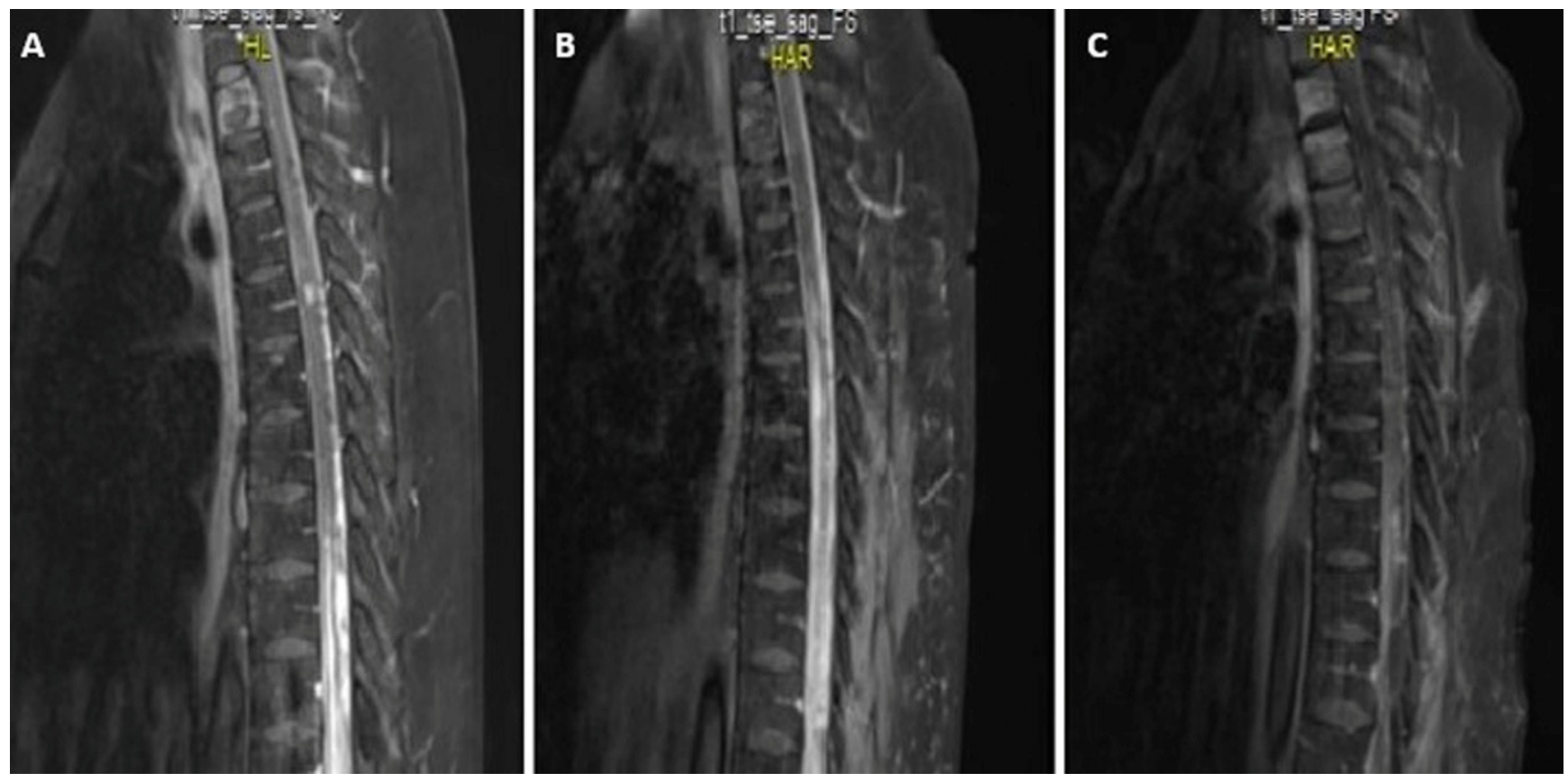

Figure 1. T1 contrast enhanced sagittal magnetic resonance imagings of thoracal region of the patient. A) At the T5 vertebra level 8x7 mm homogenously contrast enhanced intramedullary lesion (shown with an arrow) and dural heterogeneous contrast enhancement from T5 to L2 level, seen before radiotherapy (RT) and temozolomide (TMZ). B) Same lesion 9x8 mm and an increase in the contrast enhancement, after RT and TMZ therapy C) Regression of the tumors of the patient after 14 cycles of bevacizumab therapy which shows loss of contrast enhancement of the lesions. 


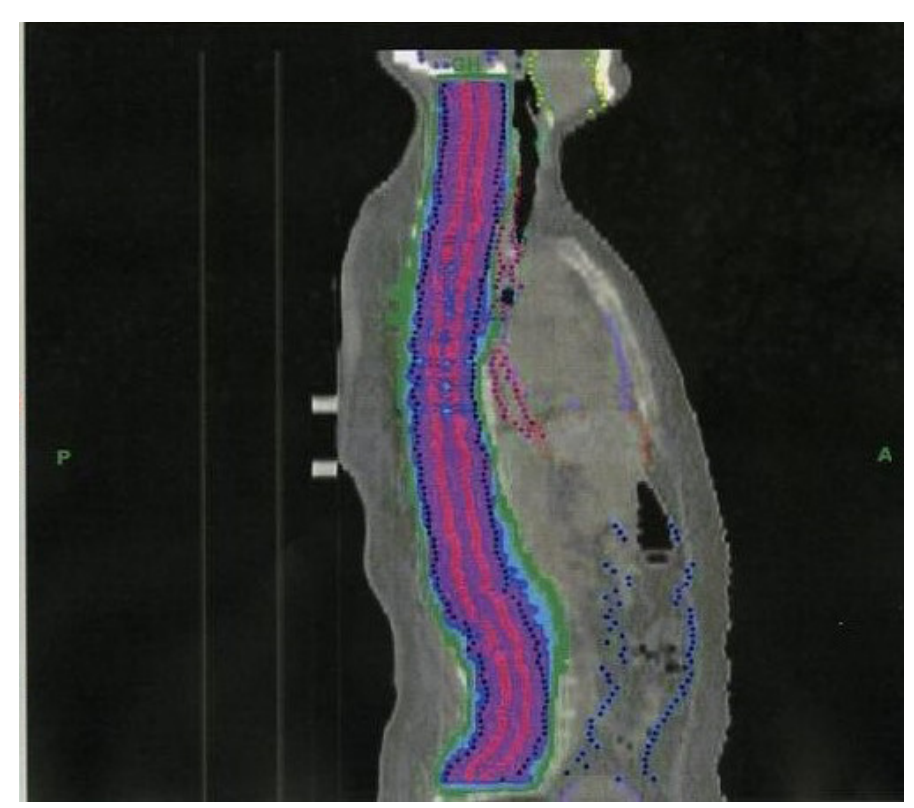

Figure 2. Sagittal view of radiation treatment area (27x1,8 cGy)
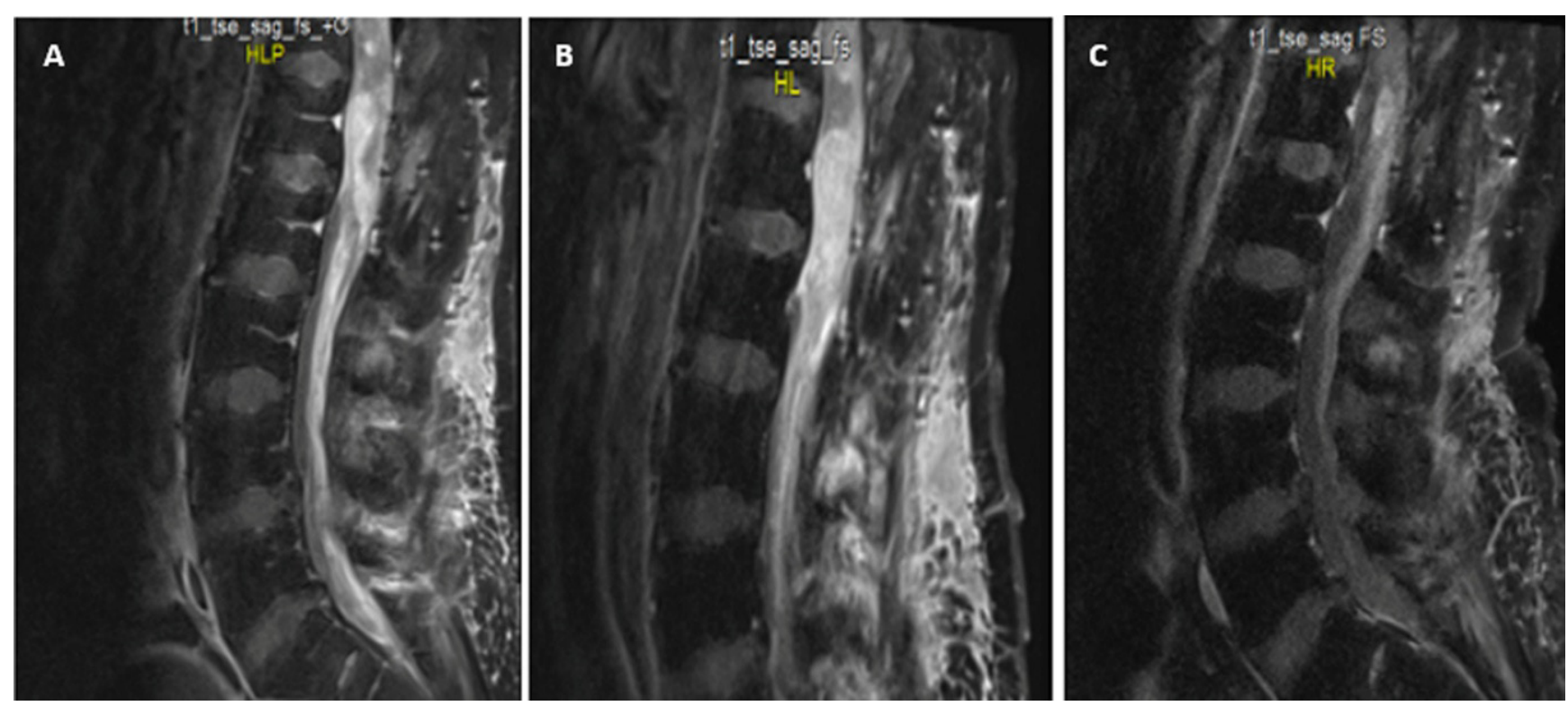

Figure 3. T1 contrast enhanced sagittal magnetic resonance imagines of thoracolomber region of the patient. A) Recurrent heterogeneously contrast enhanced lesion at the level of T12-L5 obliterating the thecal sac, before radiotherapy (RT) and temozolomide (TMZ). B) Same lesion with an increase in lesion size after RT and TMZ therapy C) Nearly total response of the tumor after 14 cycles of bevacizumab therapy with loss of contrast enhancement of the tumor

To exclude metastatic disease whole body was scanned with tomography and did not show any other lesions. Because lesion was considered inoperable, whole spinal cord radiotherapy was given between November 2017 and January 2018 with a radiotherapy dose of 48.6 Gy given in 27 fractions (Figure 2).

After radiotherapy, 3 cycles of temozolomide chemotherapy was given and MRI was performed to assess treatment response. Whole spinal MRI showed an increase in the lesion size located at T12-L2 level. Due to progression, irinotekan $\left(125 \mathrm{mg} / \mathrm{m}^{2}\right.$, every two weeks) and bevacizumab $\left(10 \mathrm{mg} / \mathrm{m}^{2}\right.$, every two weeks) chemotherapy started in May 2018. Irinotecan had to be stopped due to toxicity after 3 cycles, bevacizumab was continued alone and after 4 months of treatment, MRI showed regression and loss of contrast enhancement in all of the lesions (Figure 3). The patient stabilized after 14 cycles of bevacizumab treatment with progression free survival duration of 13-months. 


\section{DISCUSSION}

The standart treatment of newly diagnosed SCAs is gross total or subtotal safe resection. For low grade tumors, after gross total resection, observation is done, and if there's subtotal resection, local radiotherapy is often prefered. If there's a high grade tumor, clinicians usually extrapolate the intracranial glial tumor therapy results and surgery, radiotherapy and chemotherapy decision can be made (6,7). SCAs are highly fatal tumors and low-grade tumors (WHO grade I and II) also may recur and result in death (8).

The efficacy of chemotherapy is the least studied topic in the literature and after recurrence, there is no standart therapy for recurrent and radiotherapy resistant SCAs. Chemotherapy agents like lomustine, carboplatin, vincristine, and 'eight in one' chemotherapy have been used in children which showed limited effectiveness (9-12). Temozolomide is the most commonly used agent in the reported series. A retrospective study determining the role of temozolomide for recurrent low grade spinal cord adult gliomas, revealed that the overall median time to tumor progression was 14.5 months and the median survival time was 23 months $(13,14)$. In another study, temozolomide was given for recurrent high grade spinal cord glioma patients. Overall median time to progression was 6.6 months and the median survival time was 16.6 months (15). In the biggest patient number study including 83 patients with spinal astrocytomas, chemotherapy was administered to $41.8 \%$ of the patients (TMZ was the most commonly administered chemotherapeutic agent) and showed improved progression free survival in infiltrative astrocytomas (4). In our case, the tumor did not show any response and progressed after radiotherapy and temozolomide chemotherapy. Based on the data of irinotecan and bevacizumab treatment in high grade glial tumors in adults, patient received irinotecan $\left(340 \mathrm{mg} / \mathrm{m}^{2}\right)$ and bevacizumab $(10 \mathrm{mg} / \mathrm{kg})$ in every two weeks and after 12 weeks tumor regression was observed both clinically and radiologically.

In a retrospective study investigating the role of $\mathrm{TMZ}$ or bevacizumab in spinal cord high grade glioma after recurrence, median overall survival time were 16.6 months for temozolamide and 22.8 months for bevacizumab (16). The efficacy of bevacizumab for recurrent spinal cord glioblastoma was reported in a small cohort of adults $(n=6)$, who had all failed prior therapy including surgery and TMZ-based chemoradiotherapy and radiotherapy. This study showed a median survival of 9 months (17). In a recent study with the biggest number of cases in the literature, bevacizumab used as a single agent in the treatment of recurrent and refractory pediatric low grade glioma and showed $80 \%$ objective response rate (12 of 15 patients showed radiologic response) (18). In our case, a good treatment response with bevacizumab was seen in a SCA. Although, it was a low grade SCA in the first presentation, it may transform into a high grade glioma in its recurrence and this may explain the good response with bevacizumab in a patient with known low grade SCA.
But, in addition, an in vitro study showed that combining TMZ with bevacizumab significantly reduced tumor mass and increased apoptosis of tumor cells in spinal cord which also can be an evidence for the usage of bevacizumab in SCAs (19). Therefore, bevacizumab may be a treatment option for SCAs with no alternative options.

As a conclusion, limited data about bevacizumab shows promising results in SCAs. Also, in our case, we report a partial response to bevacizumab in a patient with low grade SCA but further large studies are needed for combined and effective therapies to increase the role of chemotherapy treatment in SCAs.

Conflicts of Interest and Financal Status: Our study has not been financed by an institution and institution. In this study there is no conflict of interest among the authors on any subject.

Research Contribution Rate Statement Summary: The authors declare that, they have contributed equally to the manuscript.

\section{REFERENCES}

1. Tobin MK, Geraghty JR, Engelhard HH, Linninger AA, Mehta AI. Intramedullary spinal cord tumors: a review of current and future treatment strategies. Neurosurg Focus. 2015;39(2):14.

2. Grimm $S$, Chamberlain MC. Adult primary spinal cord tumors. Expert Rev Neurother. 2009;9(10):1487-95.

3. Epstein FJ, Farmer JP, Freed D. Adult intramedullary astrocytomas of the spinal cord. J Neurosurg. 1992;77(3):355-59.

4. Fakhreddine MH, Mahajan A, Penas-Prado M, Weinberg J, McCutcheon IE, Puduvalli V et al. Treatment, prognostic factors, and outcomes in spinal cord astrocytomas. Neuro Oncol. 2013;15(4):406-12.

5. Rodrigues GB, Waldron JN, Wong CS, Laperriere NJ. A retrospective analysis of 52 cases of spinal cord glioma managed with radiation therapy. Int J Radiat Oncol Biol Phys. 2000;48(3):83742 .

6. Minehan KJ, Brown PD, Scheithauer BW, Krauss WE, Wright MP. Prognosis and treatment of spinal cord astrocytoma. Int J Radiat Oncol Biol Phys. 2009;73(3):727-33.

7. Abdel-Wahab M, Etuk B, Palermo J, Shirato H, Kresl J, Yapicier $\mathrm{O}$ et al. Spinal cord gliomas: a multi-institutional retrospective analysis. Int J Radiat Oncol Biol Phys. 2006;64(4):1060-71.

8. Roonprapunt C, Houten JK. Spinal cord astrocytomas: presentation, management, and outcome. Neurosurg Clin N Am. 2006;17(1):29-36.

9. Packer RJ, Lange B, Ater J, Nicholson HS, Allen J, Walker R et al. Carboplatin and vincristine for recurrent and newly diagnosed low-grade gliomas of childhood. J Clin Oncol. 1993;11(5):8506.

10. Lefkowitz IB, Packer RJ, Sutton LN, Siegel KR, Bruce DA, Evans $\mathrm{AE}$ et al. Results of the treatment of children with recurrent gliomas with lomustine and vincristine. Cancer. 1988;61(5):896902.

11. Allen JC, Aviner S, Yates AJ, Boyett JM, Cherlow JM, Turski PA et al. Treatment of highgrade spinal cord astrocytoma of childhood with "8-in-1" chemotherapy, radiotherapy: a pilot study of CCG-945. Children's Cancer Group. J Neurosurg. 1998;88(3):215-20. 
12. Lowis SP, Pizer BL, Coakham H, Nelson RJ, Bouffet E. Chemotherapy for spinal cord astrocytoma: can natural history be modified?. Childs Nerv Syst. 1998;14(7):317-21.

13. Chamberlain MC. Salvage chemotherapy for recurrent spinal cord ependymona. Cancer. 2002;95(5):997-1002.

14. Chamberlain MC. Temozolomide for recurrent low-grade spinal cord gliomas in adults. Cancer. 2008;113(5):1019-24.

15. Kim MS, Chung CK, Choe G, Kim IH, Kim HG. Intramedullary spinal cord astrocytoma in adults: postoperative outcome. J Neurooncol. 2001;52(1):85-94.

16. Kaley TJ, Mondesire-Crump I, Gavrilovic IT. Temozolomide or bevacizumab for spinal cord high-grade gliomas. J Neurooncol. 2012;109(2):385-89.
17. Chamberlain MC, Johnston SK. Recurrent spinal cord glioblastoma: salvage therapy with bevacizumab. J Neurooncol. 2011;102(3):427-32.

18. Gorsi HS, Khanna PC, Tumblin M, Yeh-Nayre L, Milburn M, Elster JD et al. Single-agent bevacizumab in the treatment of recurrent or refractory pediatric low-grade glioma: A single institutional experience. Pediatr Blood Cancer. 2018;65(9):e27234.

19. Gwak SJ, An SS, Yang MS, Joe E, Kim DH, Yoon DH et al. Effect of combined bevacizumab and temozolomide treatment on intramedullary spinal cord tumor. Spine. 2014;39(2):65-73. 